\title{
HUBUNGAN KADAR BETA-SITE APP-CLEAVING ENZYME 1, BETA-AMYLOID DAN 4 HYDROXINONENAL PLASMA DENGAN GANGGUAN FUNGSI KOGNITIF PADA PENDERITA PASCASTROKE ISKEMIK
}

\author{
Yuliarni Syafrita*, Yanwirastit, M Hasan Machfoed ${ }^{* * *}$, Darwin Amir \\ , "Bagian Neurologi FK-UNAND Padang, "BBagian Anatomi FK-UNAND Padang \\ ***Bagian Neurologi FK UNAIR Surabaya.
}

\begin{abstract}
ABSTRACK
Background: The level of beta-amyloid (AB) in the cerebrospinal fluid (CSS) can be used as a marker to detect cognitive impairment, but the CSS retrieval technique is invasive, so it is necessary to find biomarkers that are relatively easy, cheap and reliable. Therefore, biomarkers that can be measured in blood is needed.

Aims: To determine the association of the blood levels of BACE-1, A 3 and 4 HNE with ischemic cognitive function after stroke event.

Methods: This study was an observational study with cross sectional design using cases and controls. A number of 84 patients with ischemic stroke and 42 normal subjects as controls were enrolled. Cognitive function was assessed 3 months after stroke event using MoCA-Ina test and measurement of blood levels of BACE1-1, AB40, AB42 and 4 HNE was conducted within 72 hours of onset of stroke. Regression statistical analysis was used to determine the most dominant factors related to the occurrence of impaired cognitive function after stroke event.

Results: In bivariate analysis, we found a significant association between cognitive impairment after stroke with high blood levels of BACE1 $(p=0.004, O R=4.714)$, low levels of $A B 40(p=$ $0.0001, O R=14.80)$ and low levels of $A \beta 42(p=0.017, O R=3.44)$. There was no significant association between the blood levels of $4 H N E$ with impaired cognitive function after stroke event. In multivariate analysis, we found low low plasma level of $A \beta 40$, high level of BACE-1, and low level of $A \beta 42$ were variables strongly related with cognitive impairment after ischemic stroke subsequently based on the strength of correlation.
\end{abstract}

Conclusions: Low levels of AB40, high levels of BACE-1 and low levels of AB42 are associated with the incidence of impaired cognitive function after ischemic stroke.

Keywords: cognitive function, ischemic stroke, beta-amyloid 


\begin{abstract}
ABSTRAK
Latar Belakang: Kecacatan pascastroke diperberat oleh terganggunya fungsi kognitif. Metode diagnostik yang tersedia sekarang, tidak cukup sensitif bila digunakan sebagai upaya untuk menemukan gangguan kognitif pascastroke secara dini. Kadar beta-amyloid (A $\beta$ ) di cairan serebrospinal (CSS) dapat dijadikan sebagai penanda telah terjadinya gangguan kognitif, namun teknik pengambilan CSS adalah invasive, sehingga perlu dicari biomarker yang relatif mudah, murah dan dapat dipercaya. Untuk itu perlu dicarai biomarker pada plasma.

Tujuan : Untuk mengetahui hubungan kadar BACE-1, A $\beta$ dan 4 HNE plasma dengan fungsi kognitif pascastroke iskemik.

Metode : Penelitian ini bersifat observasional dengan disain cross sectional, menggunakan kasus dan kontrol. Mengikutkan 84 penderita pascastroke iskemik dan 42 subjek normal sebagai kontrol. Fungsi kognitif diperiksa 3 bulan pascastroke dengan test MoCA-Ina dan pemeriksaan kadar BACE1-1, AB40, AB42 dan 4HNE plasma dalam 72 jam onset stroke. . Analisa regresi statitistik digunakan untuk menetapkan faktor mana yang paling dominan hubungannya dengan terjadinya gangguan fungsi kognitif pascastroke iskemik.

Hasil: Pada analisis bivariat, ditemukan hubungan yang bermakna antara gangguan kognitif pascastroke dengan tingginya kadar BACE1 $(p=0,004, O R=4,714)$, rendahnya kadar $A \beta 40$ $(p=0,0001, O R=14,80)$ dan rendahnya kadar $A \beta 42(p=0,017, O R=3,44)$. Tidak ditemukan hubungan yang bermakna antara kadar 4 HNE dengan gangguan fungsi kognitif pascastroke. Pada analisis multivariat, didapatkan rendahnya kadar Aß40 dan tingginya kadar BACE1 plasma sebagai variabel yang kuat hubungannya dengan kejadian gangguan kognitif pascastroke iskemik.

Kesimpulan : Rendahnya kadar A 40 dan tingginya kadar BACE-1 plasma berhubungan dengan kejadian gangguan fungsi kognitif pascastroke iskemik.
\end{abstract}

Kata kunci : fungsi kognitif, stroke iskemik, beta-amyloid 
Yuliarni Syafrita dkk : Hubungan Kadar Beta-Site App-Cleaving Enzyme 1, Beta-Amyloid

\section{Pendahuluan}

Stroke merupakan penyebab utama kecacatan pada usia produktif. Stroke akan menyebabkan penurunan kualitas hidup, tidak saja hanya karena kecacatan fisik, tetapi juga karena menurunnya atau terganggunya fungsi kognitif setelah mengalami serangan stroke ${ }^{1}$.

Saat ini diagnostik gangguan kognitif pascastroke masih berdasarkan manifestasi klinis, neuroimaging dan beberapa test neuropsikologi. Semua metode ini tidak cukup sensitif bila digunakan sebagai upaya untuk menemukan gangguan kognitif dini pascastroke dan hasil pemeriksaan sangat tergantung pada kesadaran, sikap dan kooperatif dari pasien. Oleh sebab itu diperlukan suatu "penanda" (marker) yang bisa digunakan sejak dini dan objektif untuk menilai adanya gangguan kognitif pascastroke ${ }^{2}$.

Akhir-akhir inidikemukakan bahwapada otak penderita AD dan Vascular Dementia (VaD) ditemukan beberapa gambaran patologi yang sama. Andin melaporkan $40 \%$ pasien yang memenuhi kriteria klinis untuk VaD, pada biopsi otaknya ditemukan gambaran $A D$ dan dari $87 \%$ penderita yang memenuhi kriteria klinis sebagai penderita $\mathrm{VaD}$, ditemukan gambaran patologi $A D$ pada otaknya sebesar $58 \%$ dan gambaran campuran antara VaD dan AD sebesar $42 \%$ ${ }^{3}$. Ditambahkan lagi ditemukan deposit $\beta e t a-$ amyloid $(\mathrm{A} \beta)$ dan neurofibrillary tangle (NFT) pada $43 \%$ otak penderita $\mathrm{VaD}^{4}$.

Berbagai penelitian telah menemukan bahwa kadar $A \beta$ di cairan serebrospinal (CSS) dapat dijadikan sebagai penanda telah terjadinya gangguan kognitif, namun yang menjadi masalah adalah bahwa teknik pengambilan CSS melalui punksi lumbal adalah suatu teknik yang invasive, sehingga sulit untuk dilakukan ${ }^{5,6}$. Oleh karena itu akhir akhir ini telah dikembangkan upaya mencari biomarker yang relatif mudah, murah dan dapat dipercaya, dan dari berbagai biomarker yang dikembangkan, perhatian dan harapan banyak tertuju pada kadar A $\beta$ plasma ${ }^{5}$.

Adanya sumbatan pembuluh darah pada stroke iskemik, akan menyebabkan hipoksia dan penurunan aliran darah. Kondisi ini akan menyebabkan peningkatan ekspresi Beta-site APP Cleaving Enzyme 1 (BACE1), yang selanjutnya akan meningkatkan produksi $A \beta$.
Selain $A \beta$, penyakit neurodegeneratif jugadipicuolehadanyastresoxidatif. Beberapa studi terdahulu telah menemukan bahwa pada penyakit-penyakit neurodegeneratif termasuk demensia, ditemukan kadar lipid peroksidasi yang meningkat. Peroksidasi lipid dapat diukur dari sejumlah marker meliputi malondialdehyde (MDA), acrolein, isoprostan dan 4-Hydroxynonenal (4HNE). Empat Hydroxinonenal secara kimia lebih reaktif dibandingkan yang lain, sehingga lebih merusak membran lipid $^{7}$. Kruman, menemukan bahwa 4 HNE menyebabkan apoptosis neuron dan efek ini tidak terlihat pada aldehid yang lain ${ }^{8}$.

Berdasarkan latar belakang yang telah dikemukakan diatas, tujuan penelitian ini adalah untuk mengungkap hubungan kadar BACE1, A $440, A \beta 42,4 H N E$ plasma dengan kejadian gangguan fungsi kognitif pascastroke iskemik.

\section{Metode}

Telah dilakukan penelitian observasional komparatif dengan disain cross sectional, selama periode Maret hingga Desember 2013 di bagian neurologi RS Dr M Djamil Padang. Didapatkan 102 pasien stroke iskemik yang masuk rumah sakit dalam 6 72 jam onset dan memenuhi kriteria inklusi, namun dalam perjalanan penelitian 14 orang meninggal dunia dan 4 orang pindah ke propinsi lain, sehingga pemeriksaan fungsi kognitif yang dilakukan 3 bulan pascastroke hanya dapat dilakukan pada 84 pasien. Pada periode yang sama telah diperiksa juga 42 orang subjek kontrol.

Rentang usia pada kelompok kasus adalah 50 - 83 tahun $(61,11 \pm$ 8.56), dan pada kelompok kontrol 50 74 tahun(59,05 \pm 6.57$)$. Semua kasus merupakan serangan stroke iskemik yang pertama, dengan faktor resiko vaskuler. Kriteria eklusi bila menderita demensia atau telah mengalami gangguan kognitif yang bermakna sebelum mendapat serangan stroke, stroke berdarah, penurunan kesadaran, afasia dan disathria yang berat, mengalami depresi dan tidak bersedia diikutkan dalam penelitian.

Pada saat masuk rumah sakit, dilakukan anamnesis dan pemeriksaan fisik yang lengkap dan dicatat dalam medical record. Defisit 
neurologi dinilai dengan skor NIHSS. Sampel darah dalam keadaan puasa diambil dalam 6 - 72 jam onset dan dimasukkan ke dalam tabung vacutab EDTA. kemudian plasmanya di simpan pada suhu $-80^{\circ} \mathrm{C}$ untuk kelompok kasus. Untuk kelompok kontrol, sampel darah diambil dalm keadaan puasa, dimasukkan ke dalam tabung vacutab EDTA. kemudian plasmanya di simpan pada suhu $-80^{\circ} \mathrm{C}$.

\section{Pemeriksaan Neuropsikologi dengan MoCA-Ina}

Pemeriksaan kognitif dilakukan setelah 3 bulan onset untuk kelompok kasus dan segera setelah pengambilan sampel darah untuk kelompok kontrol

Berdasarkan hasil pemeriksaan MoCA-Ina ini, kelompok penelitian dibagi atas

1. Kelompok pascastroke iskemik dengan gangguan kognitif

2. Kelompok pascastroke iskemik dengan kognitif baik

3. Kelompok kontrol

\section{Analisis Biokimia}

Kadar BACE1, AB40, AB42 dan 4 HNE plasma di ukur dengan komersial double sandwich enzyme-linked immunosorbent assay (ELISA) kits (Cell Biolabs Inc, STA338. (888) CBL - 0505) sesuai menurut instruksi pabrik yang memproduksi. Semua sampel darah di analisa pada waktu yag sama, menggunakan reagansia dari pabrik yang sama di laboratorium Biomedik fakultas Kedokteran Universitas Andalas Padang, Indonesia.

\section{Analisa Statistik}

Semua perhitungan statistik dilakukan menggunakan SPSS 21.0. data dipresentasikan dalam bentuk median (min - maks). Perbedaan antara grup dianalisa dengan uji Kruskal-Wallis dengan post hoc uji Mann-Whitney. Data frekuensi dianalisis dengan test korelasi antar variable dengan chisqure, dianggap bermakna bila nilan $p<0,05$.

\section{Hasil}

Tiga bulan pascastroke, 84 pasien yang diikutkan dalam penelitian, dikelompokkan atas 44 orang $(52,4 \%)$ dengan gangguan kognitif dan 40 orang $(47,6 \%)$ dengan kognitf baik. Didapatkan juga 42 kelompok kontrol.Tidak ada perbedaan yang signifikan mengenai umur, jenis kelamin dan pendidikan, antara kelompok kasus dan kontrol $(p>0,05)$ (Tabel 1)

Tabel 1 Karakteristik Dasar Kelompok Kasus dan Kontrol

\begin{tabular}{lccc}
\hline Karakteristik Dasar & \multicolumn{2}{c}{ Subjek Penelitian } & \multirow{2}{*}{ Kasus $(n=84)$} \\
\cline { 2 - 3 } & $59,50(49-83)$ tahun $(n=84)$ & $60(49-74)$ tahun & $0,299^{*}$ \\
\hline Umur & $41 / 43$ & $19 / 23$ & $0,850^{* *}$ \\
$\begin{array}{l}\text { Kelamin } \\
\text { Laki/Perempuan }\end{array}$ & & \\
$\begin{array}{l}\text { Pendidikan } \\
\text { Rendah/Tinggi }\end{array}$ & $56 / 28$ & $33 / 9$ & $0,192^{* *}$ \\
\hline
\end{tabular}

\footnotetext{
* Uji Mann Whitney U
}

* Uji Chi-square 


\section{Pemeriksaan Fungsi Kognitif}

Pemeriksaan fungsi kognitif dilakukan setelah 3 bulan onset serangan stroke dan pada kelompok kontrol, langsung diperiksa setelah pengambilan sampel darah dengan menggunakan instrument MoCA-Ina. Seperti terlihat pada tabel 2, gangguan kognitif lebih banyak ditemukan pada kelompok kasus $(52,4 \%)$ dibanding kontrol $(16,7 \%)$. Perbedaan ini bermakna secara statistik dengan nilai $p=0,0001$ dan nilai OR 5,5

Tabel 2. Distribusi Gangguan Kognitif pada Kelompok Kasus dan Kelompok Kontrol

\begin{tabular}{|c|c|c|c|c|c|c|}
\hline & \multicolumn{2}{|c|}{$\begin{array}{l}\text { Fungsi } \\
\text { Terganggu }\end{array}$} & \multicolumn{2}{|c|}{$\begin{array}{l}\text { Fungsi } \\
\text { Normal }\end{array}$} & \multirow[t]{2}{*}{$p$} & \multirow[t]{2}{*}{ OR } \\
\hline & $n$ & $\%$ & $n$ & $\%$ & & \\
\hline Kelompok Kasus & 44 & 52,4 & 40 & 47,6 & 0,0001 & 5,5 \\
\hline Kelompok Kontrol & 7 & 20,6 & 35 & 79,4 & & \\
\hline
\end{tabular}

Pemeriksaan BACE1, $A \beta 40, A \beta 42$ dan 4HNE serta MoCA-Ina

Kadar BACE1, AB40, AB42 dan 4HNE plasma serta MoCA_Ina pada kelompok kasus dan kelompok kontrol, diperlihatkan pada table 3 dibawah ini. Ditemukan perbedaan yang bermakna, kadar $A \beta 40$, Aß42 dan 4HNE plasma dan nilai MoCA-Ina antara kelompok kasus dan kontrol.

Tabel 3. Distribusi Nilai BACE1, AB40, Aß42 dan 4HNEserta MoCA-Ina Kelompok Kasus dan Kelompok Kontrol

\begin{tabular}{llll}
\hline Variabel & \multicolumn{2}{c}{ Subjek Penelitian } & \\
\cline { 2 - 4 } & Kasus $(n=84)$ & Kontrol $(n=42)$ & \\
\hline BACE-1 & $21.89 n g(1,25-52,53)$ & $19,42 n g(7,16-102,20)$ & $0,456^{*}$ \\
Kadar AB40 & $461,12 p g(9.62-1185.22)$ & $1077,95 p g(46,82-2739.51)$ & $<0,001^{*}$ \\
Kadar AB42 & $29,82 p g(0,26-88.19$ & $8.79 p g(1,05-28,19)$ & $<0,001^{*}$ \\
4HNE & $2,29 \mu g(2,19-2,69)$ & $0,92 \mu g(0,90-0,95)$ & $<0,001^{*}$ \\
MoCA-Ina & $21,00 \pm 4,84$ & $27,5 \pm 3,32$ & $<0,001^{*}$ \\
\hline
\end{tabular}

* Man Whitney U Test 
Perbedaan Kadar BACE1, A 340 , A 342 dan 4HNE Plasma Kelompok Kasus dengan Gangguan Kognitif dan Tanpa Gangguan Kognitif.

Didapatkan peninggian kadar BACE1 dan penurunan kadar $A \beta 40, A \beta 42$ dan $4 \mathrm{HNE}$ plasma pada kelompok kasus dengan gangguan kognitif dibanding kelompok kasus tanpa gangguan kognitif, seperti terlihat pada tabel 4 berikut ini.

Didapatkan peninggian kadar BACE1 pada kelompok kasus dengan gangguan kognitif, yang berbeda bermakna dibandingkan kasus tanpa gangguan kognitif. Didapatkan penurunan kadar $A B 40$ dan Aß42 pada kelompok kasus dengan gangguan kognitif, yang berbeda bermakna dibandingkan kasus tanpa gangguan kognitif dan didapatkan juga penurunan kadar 4 HNE pada kelompok kasus dengan gangguan kognitif namun tidak berbeda bermakna dibandingkan kasus tanpa gangguan kognitif

Tabel 4. Distribusi Kadar BACE1, AB40, AB42 dan 4 HNE Plasma Kelompok Kasus dengan Gangguan Kognitif dan Tanpa Gangguan Kognitif.

\begin{tabular}{|c|c|c|c|c|}
\hline Variabel & Kelompok & $n$ & Median(min-max) & $p$ \\
\hline \multirow[t]{2}{*}{ BACE-1 } & $\begin{array}{l}\text { Kasus dengan } \\
\text { gangguan kognitif }\end{array}$ & 44 & $25,69 \mathrm{ng}(5,03-47,68)$ & $0,012^{*}$ \\
\hline & $\begin{array}{l}\text { Kasus tanpa gangguan } \\
\text { kognitif }\end{array}$ & 40 & $18,58 \mathrm{ng}(1,25-52,53)$ & \\
\hline \multirow[t]{2}{*}{$A \beta 40$} & $\begin{array}{l}\text { Kas u s d e n g a n } \\
\text { gangguan kognitif }\end{array}$ & 44 & $395,75 \mathrm{pg}(9,6-565.7)$ & $<0,001^{*}$ \\
\hline & $\begin{array}{l}\text { Kasus tanpa gangguan } \\
\text { kognitif }\end{array}$ & 40 & 539,56 pg $(285,69-1185.22)$ & \\
\hline \multirow[t]{2}{*}{$\mathrm{A} \beta 42$} & $\begin{array}{l}\text { Kasus dengan } \\
\text { gangguan kognitif }\end{array}$ & 44 & $20,51 \mathrm{pg}(0,29-66,04)$ & $0,001^{*}$ \\
\hline & $\begin{array}{l}\text { Kasus tanpa gangguan } \\
\text { kognitif }\end{array}$ & 40 & $35,57 \mathrm{pg}(0,26-88,19)$ & \\
\hline \multirow[t]{2}{*}{ 4HNE } & $\begin{array}{l}\text { Kasus dengan } \\
\text { gangguan kognitif }\end{array}$ & 44 & $2.28 \mu g(2,19-2.60)$ & $0,065^{*}$ \\
\hline & $\begin{array}{l}\text { Kasus tanpa gangguan } \\
\text { kognitif }\end{array}$ & 40 & $2.29 \mu g(2,23-2.69)$ & \\
\hline
\end{tabular}

*Mann-Whitney U Test

Hubungan kadar BACE1, A $400, A \beta 42$ dan $4 \mathrm{HNE}$ plasma dengan Fungsi Kognitif

Hubungan kadar BACE1, AB40, Aß42 dan 4 HNE plasma dengan fungsi kognitif dapat dilihat pada table 4 dibawah ini. Oleh karena masing masing variabel belum mempunyai nilai normal, maka untuk menentukan apakah nilai yang didapatkan tinggi atau rendah, maka dicari nilai cut off point masing-masing variabel terhadap fungsi kognitif (MoCA-Ina $=26$ ) dengan prosedur Receiver Operating Characteristic (ROC), sehingga masing-masing variabel bisa dikelompokkan berdasarkan nilai cut off point tersebut. Dikatakan tinggi bila nilai variabel > cut off point dan dikelompokkan rendah bila nilai $\leq$ cut off point. 
Yuliarni Syafrita dkk: Hubungan Kadar Beta-Site App-Cleaving Enzyme 1, Beta-Amyloid

Tabel 4. Hubungan kadar BACE1, Aß40, Aß42 dan 4HNE plasma dengan Fungsi Kognitif

\begin{tabular}{|c|c|c|c|c|}
\hline \multirow[t]{2}{*}{ Jenis Variabel } & \multicolumn{2}{|c|}{ Fungsi Kognitif } & \multirow[b]{2}{*}{$p$} & \multirow[b]{2}{*}{ OR } \\
\hline & $\begin{array}{c}\text { Terganggu } \\
n=44\end{array}$ & $\begin{array}{c}\text { Tak Terganggu } \\
n=40\end{array}$ & & \\
\hline \multirow{2}{*}{$\begin{array}{l}\text { BACE1 Tinggi } \\
\text { BACE1 Rendah }\end{array}$} & 22 & 7 & \multirow[t]{2}{*}{$0,004^{*}$} & \multirow[t]{2}{*}{$4,714(1,722-12.907)$} \\
\hline & 22 & 33 & & \\
\hline \multirow{2}{*}{$\begin{array}{l}\text { Aß40 Rendah } \\
\text { Aß40 Tinggi }\end{array}$} & 24 & 3 & \multirow[t]{2}{*}{$<0,001^{*}$} & \multirow[t]{2}{*}{$14,80(3,963-55,278)$} \\
\hline & 20 & 37 & & \\
\hline Aß42 Rendah & 22 & 9 & \multirow[t]{2}{*}{$0,017^{*}$} & \multirow[t]{2}{*}{$3,44(1,334-8,894)$} \\
\hline Aß42 Tinggi & 22 & 31 & & \\
\hline \multirow{2}{*}{$\begin{array}{l}\text { 4HNE Tinggi } \\
\text { 4HNE Rendah }\end{array}$} & 21 & 25 & \multirow[t]{2}{*}{$0,255^{*}$} & \multirow[t]{2}{*}{$0,548(0,23-1,31)$} \\
\hline & 23 & 15 & & \\
\hline
\end{tabular}

\section{"Pearson Chi-Square}

Ditemukan hubungan yang bermakna antara kadar BACE-1, AB40 dan AB42 plasma pada fase akut stroke dengan fungsi kognitif 3 bulan pasca stroke, dan tidak ada hubungan untuk kadar $4 \mathrm{HNE}$ plasma.

\section{Variabel Yang Paling Dominan Hubung-} annya Dengan Terjadinya Gangguan Fungsi Kognitif Pascastroke Iskemik

Untuk melihat, variabel mana yang paling dominan pengaruhnya terhadap terjadinya gangguan fungsi kognitif, maka dilakukan analisis multivariat dengan regresi logistik. Variabel yang diikutkan dalam analisis multivariat adalah variabel yang pada uji bivariat mempunyai nilai $p<0,25$. Oleh karena itu, variabel yang diikutkan dalam langkah 1 adalah kadar BACE1, AB40, dan Aß42.

Pada langkah 2, terlihat bahwa ada peningkatan nilai OR AB40 > $10 \%$, yang berarti bahwa $A \beta 42$ yang dikeluarkan pada langkah 2 mempunyai kontribusi yang tidak bisa diabaikan, maka yang dpakai adalah langkah 1 seperti berikut

Tabel 5.10. Variabel Yang Paling Dominan Hubungannya Dengan Terjadi-nya Gangguan Fungsi Kognitif Pascastroke Iskemik

\begin{tabular}{lllll}
\hline & Variabel & Koefisien & $p$ & OR(IK95\%) \\
\hline Langkah 1 & BACE1 & 1,709 & 0,004 & $5,522(1,720-17,728)$ \\
& AB40 & 2,688 & 0,000 & $14,703(3,621-59,698)$ \\
& AB42 & 0,924 & 0,112 & $2,519(0,806-7,876)$ \\
& Konstanta & $-1,527$ & 0,000 & 0,217 \\
Langkah 2 & BACE1 & 1,791 & 0,001 & $5,994(1,888-19,028)$ \\
& AB40 & 2,874 & 0,000 & $17,700(4,394-71,298)$ \\
& Konstanta & $-1,256$ & 0,001 & 0,285 \\
\hline
\end{tabular}




\begin{tabular}{lllll}
\hline & Variabel & Koefisien & $p$ & OR(IK95\%) \\
\hline Langkah 1 & BACE1 & 1,709 & 0,004 & $5,522(1,720-17,728)$ \\
& A 40 & 2,688 & 0,000 & $14,703(3,621-59,698)$ \\
& A 42 & 0,924 & 0,112 & $2,519(0,806-7,876)$ \\
& Konstanta & $-1,527$ & 0,000 & 0,217 \\
\hline
\end{tabular}

Setelah dilakukan analisis multivariat, didapatkan variabel yang paling kuat hubungannya dengan terjadinya gangguan fungsi kognitif pascastroke adalah rendahnya kadar A 440 $(\mathrm{OR}=14,703)$ diikuti oleh tingginya kadar BACE1 $(\mathrm{OR}=5,522)$ dan rendahnya kadar A 42( $\mathrm{OR}=2,519$ )

\section{Diskusi}

Telah dilakukan penelitian terhadap 84 penderita pascastroke iskemik dan 42 orang subjek kontrol yang mempunyai umur, pendidikan dan jenis kelamin yang setara secara statistik dengan kelompok kasus $(p>$ $0,05)$.

Untuk nilai MoCA-Ina antara kelompok kasus dan kontrol terdapat perbedaan hasil yang berbeda bermakna secara statistik (uji Mann Whitney $U$ ), dengan nilai $p<0,001$, yaitu nilai MoCA-Ina kasus lebih rendah dengan nilai rata-rata $21,00(12$ - 29) dibanding kontrol yaitu $27,50(15-30)$.

Didapatkan angka kejadian gangguan kognitif pascastroke sebesar 52,4\% (44 dari 84 kasus) dan pada kelompok kontrol didapatkan hanya sebesar 16,7\% (7 dari 42 orang), dari uji chi-square diketahui bahwa penderita pascastroke mempunyai risiko 5,50 kali lebih tinggi untuk menderita gangguan fungsi kognitif dibanding subjek nonstroke pada usia dan tingkat pendidikan yang sama.

Angka ini tidak jauh beda dari angka yang dilaporkan oleh beberapa peneliti seperti Yin (2006) melaporkan bahwa lebih dari 64\% pasien pascastroke memperlihatkan bebagai derajad gangguan kognitif. Barba (2000) melaporkan juga bahwa sekitar seperempat pasien stroke yang bertahan hidup, akan menderita demensia dalam 12 bulan setelah mendapat serangan stroke. Lebih rinci lagi Leys (2005) dari suatu studi longitudinal melaporkan bahwa prevalensi demensia berturut-turut dalam 2 minggu, 3 bulan dan 6 bulan pascastroke adalah $16,3 \%, 32,0 \%$ dan 13,6 sampai $31,8 \%$.

Tingginya kejadian gangguan kognitif pascastroke yang didapatkan pada penelitian ini, mungkin disebabkan oleh beberapa hal, seperti tingkat pendidikan kasus pada penelitian ini sebagian besar tingkat pendidikannya rendah ( $<12$ tahun), yang berbeda dari penelitian lain (Khedr 2009), selain itu mungkin juga disebabkan oleh adanya perbedaan kriteria inklusi pada masing-masing penelitian.

\section{Perbedaan Kadar BACE1, AB40, AB42 dan 4 HNE plasma Kelompok Kasus dan Kontrol}

Ditemukan peninggian kadar BACE-1 plasa pada kasus dibanding kontrol, namun tidak berbeda bermakna secara statistik. $(p=0,456)$, namun ditemukan peninggian kadar'BACE-1 pada kelompok kasus dengan gangguan kognitif dibanding kelompok kasus tanpa gangguan kognitif dan perbedaan ini bermakna secara statistik $(p=0,012)$.

Qian L (2012) pada penelitiannya terhadap 123 orang pasien pascastroke, menemukan ada hubungan peninggian kadar BACE-1 serum pada fase akut stroke dengan gangguan fungsi kognitif dibanding kelompok tanpa gangguan fungsi kognitif dan kelompok kontrol. Dilaporkan juga bahwa pada kelompok dengan gangguan kognitif, ditemukan adanya genotype Apolipoprotein $\mathrm{E}$ alel $3 / 4$ dan alel 4 . Tidak ada hubungan yang bermakna antara beratnya stroke dan volume lesi dengan gangguan kognitif. Temuan peninggian kadar BACE pada penelitian ini, sama dengan yang dilaporkan oleh Qian L, namun disini peneliti tidak menghubungkannya dengan genotype dan alel APOE'.

Ditemukan kadar Aß40 yang lebih rendah pada kelompok kasus dengan gangguan kognitif dibanding kelompok kasus 
tanpa gangguan kognitif, dan secara statistik perbedaan ini bermakna. Didapatkan juga kadar Aß40 yang lebih rendah pada kelompok kasus dengan gangguan kognitif dibanding kontrol dan secara statisik perbedaan ini juga bermakna.

Hal ini mungkin disebabkan, selain telah membentuk cerebral amyloid angiopathy, telah terjadi gangguan pembersihan betaamyloid dari otak ke sistemik, sehingga meskipun produksinya meningkat karena meningkatkan aktivasi dan ekspresi BACE1, namun kadarnya di sistemik (plasma) tetap rendah karena sebagian besar hasil produksi Aß40 di otak tidak dikeluarkan ke sistemik. Gangguan pembersihan beta-amyloid dari otak ke sistemik, sepertinya sudah terjadi sebelum serangan stroke, hal ini sesuai dengan pernyataan Jak, bahwa jauh sebelum gejala klinis gangguan kognitif muncul, sudah terjadi gangguan dan perubahan neuropatofisiologi di otak, disebabkan oleh berbagai faktor risiko vaskuler ${ }^{2}$.

Didapatkan penurunan kadarAß42 pada kelompok kasus dengan gangguan kognitif di banding kelompok kasus tanpa gangguan kognitif, dan perbedaan ini bermakna secara statistik ( $p=0,001)$. Didapatkan peningkatan kadar Aß42 pada kelompok kasus dengan gangguan kognitif dibanding kelompok kontrol dan perbedaan ini bermakna secara statistik $(p=0,013)$.

Peninggian kadar A 42 plasma pada kelompok kasus (baik dengan gangguan kognitif, maupun tanpa gangguan kognitif) dibanding kontrol ada hubungan dengan peninggian kadar BACE-1 akibat hipoksia serebri, sehingga BACE-1 akan memecah transmembran APP, membentuk AB40 dan Aß42.

Monro dari penelitiannya pada hewan coba melaporkan bahwa afinitas LRP1 (reseptor yang membantu pengeluaran $A B$ dari otak ke perifer via $B B B$ ) terhadap $A B 42$ lebih besar dibandingkan terhadap $A \beta 40$. Hal ini merupakan salah satu sebab, mengapa pada pasien pascastroke, kita menemukan peninggian kadar $A \beta 42$ dan penurunan kadar $A B 40^{10}$.

Untuk kelompok kasus pascastroke dengan gangguan kognitif didapatkan kadar 4 HNE plasma yang rendah dibandingkan kelompok kasus pascastroke tanpa gangguan kognitif, dan perbedaan ini tidak bermakna secara statistik dengan nilai $p=$
0,065. Ditemukan peningkatan kadar $4 \mathrm{HNE}$ plasma pada kelompok kasus dengan gangguan kognitif dibanding kelompok kontrol dengan nilai $p<0,001$.

Lee melaporkan bahwa ditemukan peninggian kadar 4HNE plasma pada pasien stroke iskemik dibandingkan individu normal, dan kadar 4 HNE plasma berhubungan positif dengan kadar homosistein plasma. Diduga juga 4 HNE merupakan suatu biomarker potensial untuk stroke iskemik ${ }^{11}$.

Pada penelitian ini ditemukan peninggian kadar 4HNE pada semua kasus pascastroke dan peninggian kadar $4 \mathrm{HNE}$ ini tidak berhubungan dengan kejadian gangguan fungsi kognitif pascastroke. Peninggian kadar 4HNE pascastroke yang hampir 2,5 kali lipat dibanding subjek kontrol, menggambarkan beratnya proses stres oksidatif yang terjadi pada proses infark serebri (stroke). Hasil ini hampir sama dengan yang dilaporkan oleh Lee dalam penelitiannya menemukan peninggian kadar $4 \mathrm{HNE}$ pada pasien stroke akut 3 kali lipat lebih tinggi dibandingkan kadar 4 HNE pada subjek nonstroke ${ }^{11}$.

Pada analisis bivariat hubungan kadar BACE-1 dengan fungsi kognitif, ditemukan hubungan yang bermakna antara kadar BACE-1 dengan gangguan fungsi kognitif pascastroke setelah uji statistik Chi-Square dengan nilai $p=0,004$. Kasus yang memiliki kadar BACE-1 tinggi, memiliki risiko untuk mengalami gangguan kognitif sebesar 4,714 kali lebih tinggi dibandingkan kasus yang memiliki kadar BACE-1 yang rendah.

Pada penelitian ini ditemukan adanya hubungan antara peningkatan kadar BACE1 dengan kejadian gangguan kognitif, namun keterlibatan enzim ini terhadap gangguan fungsi kognitif, tidaklah secara langsung, tapi melalui pembentukan beta-amyloid, baik $A \beta 40$ maupun $A \beta 42$.

Pada analisis bivariat hubungan kadar Aß40 dengan fungsi kognitif pascastroke ditemukan hubungan yang bermakna antara rendahnya kadar A 40 plasma dengan gangguan fungsi kognitif pascastroke setelah uji statistik Chi-Square dengan nilai $p=0,0001$. Kasus yang memiliki kadar Aß40 plasma yang rendah memiliki risiko untuk mengalami gangguan kognitif sebesar 14,80 kali lebih tinggi dibandingkan kasus pascastroke yang memiliki kadar AB40 plasma yang tinggi. Rendahnya kadar $A \beta 40$ 
plasma, mencerminkan besarnya akumulasi Aß40 di otak.

Mekanisme pasti, bagaimana betaamyloid menimbulkan gangguan kognitif belum diketahui, tetapi dari percobaan pada hewan coba diketahui bahwa bentuk oligomer dari $A \beta$ adalah bentuk $A \beta$ yang paling toksik terhadap sinaps. Pada hipokampus binatang coba diketahui bahwa $A \beta$ oligomer menurunkan LTP dan melalui reseptor glutamat dapat meningkatkan LTD dan menurunkan densitas tonjolan dendrit ${ }^{12}$. Mekanisme inilah yang melatarbelakangi terjadinya gangguan fungsi kognitif

Pada analisis bivariat hubungan kadar AB42 dengan fungsi kognitif pascastroke ditemukan hubungan yang bermakna antara rendahnya kadar Aß42 plasma dengan gangguan fungsi kognitif pascastroke setelah uji statistik Chi-Square dengan nilai $p=0,017$. Kasus pascastroke yang memiliki kadar Aß42 plasma yang rendah memiliki risiko untuk mengalami gangguan kognitif sebesar 3,44 kali lebih tinggi dibanding kasus pascastroke yang memiliki kadar $A \beta 40$ plasma yang tinggi.

Pada analisis bivariat hubungan kadar 4HNE dengan fungsi kognitif pascastroke tidak ditemukan hubungan yang bermakna antara kadar 4HNE plasma dengan gangguan fungsi kognitif pascastroke setelah uji statistik Chi-Square dengan nilai $p=0,255$.

McGrath melaporkan bahwa terdapat peninggian kadar 4-HNE plasma pada kasus dibanding kontrol pada penelitian terhadap 29 pasien yang didiagnosis dengan gangguan kognitif ${ }^{13}$. Tingginya kadar $4 \mathrm{HNE}$ plasma pada penderita pascastroke pada penelitian ini (hampir 2,5 kali lipat dibanding kontrol) menggambarkan besarnya dampak stres oksidatif terhadap lipid peroksidasi di otak.

Dari hasil analisis multivariat terhadap tiga variabel bebas yang diikutkan dalam analisis ini, ditemukan urutan kekuatan variabel yang berhubungan dengan munculnya gangguan fungsi kognitif pascastroke iskeemik yaitu rendahnya kadar A 40 , meninggkatnya kadar BACE-1 dan rendahnya kadar $A \beta 42$ plasma.

\section{SIMPULAN}

1. Ditemukan perbedaan rerata kadar BACE1 plasma penderita pascastroke iskemik yang mengalami gangguan kognitif dibanding penderita pascastroke iskemik tanpa gangguan kognitif dan dengan kelompok kontrol.

2. Ditemukan perbedaan rerata kadar $A \beta 40$ dan $A \beta 42$ plasma penderita pascastroke iskemik dengan gangguan kognitif dibanding penderita pascastroke iskemik tanpa gangguan kognitif dan dengan kelompok kontrol.

3. Ditemukan perbedaan rerata kadar 4HNE plasma penderita pascastroke iskemik dengan gangguan kognitif dibanding kelompok kontrol.

4. Ditemukan hubungan antara tingginya kadar BACE-1 dengan gangguan fungsi kognitif pascastroke.

5. Ditemukan hubungan antara rendahnya kadar Aß40 dengan gangguan fungsi kognitif pascastroke.

6. Ditemukan hubungan antara rendahnya kadar Aß42 plasma dengan gangguan fungsi kognitif pascastroke.

7. Tidak ditemukan hubungan antara kadar $4 \mathrm{HNE}$ plasma pascastroke dengan gangguan fungsi kognitif.

8. Rendahnya kadar $A \beta 40$, tingginya kadar BACE-1 dan rendahnya kadar AB42 plasma merupakan urutan kekuatan variabel yang berhubungan dengan munculnya gangguan fungsi kognitif pascastroke iskemik. .

\section{SARAN}

1. Untuk mengetahui seberapa besar pengaruh factor risiko vaskuler (confounding factor) terhadap kejadian gangguan fungsi kognitif pascastroke, disarankan untuk memasukkan variabel ini kedalam analisis pada penelitian berikutnya.

2. Mengikutsertakan dalam penelitian ini individu yang mempunyai faktor risiko vaskuler, namun tidak menderita stroke, sebagai subjek kontrol.

3. Memperhitungkan ada tidaknya gangguan kognitif sebelum penderita mengalami stroke. 


\section{DAFTAR KEPUSTAKAAN}

1. Iemolo F, Duro G, Rizzo C, Castiglia L, Hachinski V, Caruso C.. Pathophysiology of vascular dementia. Immun Ageing 2009; 6: 13

2. Jak $A J$, Bangen $K J$, Wierenga $C E$, Wood LD, Bloom JC, Bondi MW. Contributions of Neuropsychology and Neuroimaging to Understanding Clinical Subtypes of Mild Cognitive Impairment. Int Rev Neurobiol 2009; $84: 81-103$

3. Andin U, Gustafson L, Passant U, Brun A. A clinicopathologycal study of heart and brain lesion in vascular dementia. Dement Geriatr Cogn Disord 2005; 19: 222 - 22

4. Kalaria RN. Comparison between Alzheimer's disease and vascular dementia: implications for treatment. Neurol Res 2003; 25:661-4

5. Seppala TT, Herukka SK, Hanninen $T$, et al. Plasma $A \beta 42$ and $A \beta 40$ as marker of cognitive in follow-up : a prospective, longitudinal, populationbased cohort study. J Neurol Neurosurg Psychiatry 2010; doi: 10, 1136/jnnp

6. Schupf N, Tang MT, Fukuyama $\mathrm{H}$, et al. Peripheral $A \beta$ subspecies as risk biomarkers of Alzheimer's disease. PNAS September 2008; 16, vol. 105 no, $3714052-1405$

7. Axelsen $\mathrm{PH}$, Komatsu H, Murray IVJ. Oxidative Stress and Cell Membranes in the Pathogenesis of Alzheimer's Disease. Physiology 2011; vol. 26 no.1:54-69.
8. Kruman I, Bruce-Keller AJ, Bredesen D, Waeg G, Mattson MP. Evidence that 4-hydroxynonenal mediates oxidative stress-induced neuronal apoptosis. J Neurosci 1997;17:5089100

9. Qian L, Ding L, Cheng L, et al. Early biomarkers for post-stroke cognitive impairment, J Neurol 2012; 259(10):2111-8

10. Monro OR, Mackic JB, Yamada S, et al. Substitution at codon 22 reduces clearance of Alzheimer's amyloidbeta peptide from the cerebrospinal fluid and prevents its transport from the central nervous system into blood. Neurobiol Aging 2002;23(3):405-12

11. Lee WC, Wong HY, Chai $Y Y$, et al. Lipid peroxidation dysregulation in ischemic stroke: plasma 4-HNE as a potential biomarker?, Biochem Biophys Res Commun 2012; 425(4):842-7

12. Shankar GM, Li S, Mehta TH, et al. Amyloid-beta protein dimers isolated directly from Alzheimer's brains impair synaptic plasticity and memory. Nat Med 2008;14:837-842

13. McGrath LT, McGleenon BM, Brennan S, McColl D, MclLroy S and Passmore AP. Increased oxidative stress in Alzheimer's disease as assessed with 4-hydroxynonenal but not malondialdehyde. QJM 2001; 94 (9): 485-490. 